\title{
The Effectiveness of School Choice: A Value Analytical Approach
}

\author{
Kelli R. Rogers \\ University of Texas at Arlington \\ 701 S Nedderman Dr \\ Arlington, TX 76019, USA
}

\begin{abstract}
Closing the academic achievement gap between low-income and minority students and their more affluent white peers has been a long-standing concern of parents, educators, and policymakers and was set as a national priority by the No Child Left Behind (NCLB) Act of 2001. While the achievement gap is generally considered as a matter of race and class, its spatial aspects-the inequalities of academic achievement across schools and between different geographical settings (e.g., urban/suburban/rural) are largely under-researched. This paper examines the impact and effectiveness of School Choice, a key element of NCLB.NCLB is evaluated through the lens of a comprehensive seven-step framework that incorporates components of social problem analysis, valuecritical policy analysis, and choice models of Dolgoff and Feldstein (2003) and Gilbert and Terrell (2010). This analysis is based on data retrieved from a review of the literature, and implications relevant to practitioners and policymakers are highlighted.
\end{abstract}

Keywords: policy analysis model; school choice; No Child Left Behind; academic achievement gap; school resegregation; social stratification; low-income minority students; racial and socioeconomic disparities

\section{Introduction}

Education has long been recognized as important to individual well-being and for the societies in which educated people live. A better-educated population is associated with more democracy and increased civic participation, higher economic growth, and a better functioning economy (Oyserman \& Lewis, 2017). Yet, disparities in educational opportunities, attainment, and achievement exist among different student populations in the United States (Nielsen, 2013). One of the most pressing issues in American public education is the academic achievement gap. For many years, persistent disparities have existed between low-income, minority students and their more privileged White peers in all indicators of academic success including standardized test scores, grade point averages, high school graduation rates, enrollment in advanced courses, and college admission data (Zhao, 2016). Closing this achievement gap has been a long-standing concern of parents, educators, and policymakers, and was set as a national priority by the No Child Left Behind (NCLB) Act of 2001. While the achievement gap is generally considered as a matter of race and class, its spatial aspects - the inequalities of academic achievement across schools and between different geographical settings (e.g., urban/suburban/rural) are largely underresearched (Zhang \& Cowen, 2009).

Centering on solving the problem of achievement gaps, school choice has been a popular reform approach since the 1980s. With the goal of improving public school quality and giving parents new educational options and a more active role in choosing schools that they believe will provide better educational opportunities for their children, the NCLB Act is the first federal law that makes school choice available for students who are enrolled in low-performing or unsafe schools. As a result, various school choice options such as intradistrict and interdistrict open enrollment, charter schools and magnet schools, supplemental educational services, and tuition vouchers for private schools are available in many states. According to the NCLB Act, public schools receiving Title Ifunding, and that have been identified by the state as needing improvement, corrective action, or restructuring for two or more consecutive years, must allow parents the option to transfer their child out of the public school to which they normally would be assigned based on residence to another public school or provide free tutoring or remedial help (Thomas, 2011). 
While school choice under the NCLB legislation is imperative, a major concern is about the geographical inequalities in the distribution of alternative opportunities. Even though the U.S. Supreme Court struck down the legality of segregation in U.S. public schools in the 1954 landmark decision Brown v. Board of Education, resegregation has become prevalent in some school districts.

Moreover, court decisions in recent decades have made it more challenging for districts to maintain integrated schools (Welsh, 2018). Critics of NCLB argue that school choice promotes patterns of racial segregation and social class stratification among public schools. A most commonly perceived spatial inequality is that economically disadvantaged, inner city schools often perform lower than their counterparts in affluent, suburban communities. While a variety of factors are related to this achievement gap, substantial research has confirmed that the poor performance of inner city schools is primarily associated with the underprivileged socioeconomic backgrounds of their student population (Zhang \& Cowen, 2009). This paper examines the impact and effectiveness of school choice, a key element of NCLB.NCLB is evaluated through the lens of a comprehensive seven-step framework that incorporates components of social problem analysis, value-critical policy analysis, and choice models of Dolgoff and Feldstein (2003) and Gilbert and Terrell (2010). This analysis is based on data retrieved from a review of the literature, and implications relevant to practitioners and policymakers are highlighted.

\subsection{Literature Review}

Low-income, minority students, from the time they enter grade school through their postsecondary education, lose more educational ground and excel less frequently than their more affluent White peers (Ford, 2011). According to the National Assessment of Educational Progress (2015), by the end of the fourth grade, low-income, minority students are two years behind their wealthier, predominantly White peers in reading and math. By eighth grade these students have slipped three years behind, and by twelfth grade four years behind. A growing body of research has addressed the impact of neighborhood socioeconomic status on academic achievement. This occurs as a result of public schools being mainly funded by local property taxes and serving students who are mainly from the neighborhood in which the school is located. Research suggests that, due to the residentially based school assignment policy in the U.S., disparities in socioeconomic conditions across neighborhoods perpetuate the variation in academic quality across public schools. Public school located in affluent neighborhoods are more likely to perform well, while schools in low-income neighborhoods are more likely to be low-performing (Zhang \& Cowen, 2009). Minority children living in poverty tend to be concentrated in these low-performing schools, which are typically staffed by ill-equipped teachers (Murnane, 2007).

Progress made as a result of the Civil Rights Movement allowed many ethnic minority, students' access to quality schools outside of their neighborhoods, which meant these students had access to well-funded, racially mixed schools with high quality curriculum and experienced, effective teachers. However, these opportunities steadily declined in the years following the Civil Rights Era. By 2000, resegregated schools were the norm, with children of color attending majority-ethnic-minority schools, with low-income student populations. Nationally, lessqualified teachers are disproportionately found in schools with greater number of ethnic minority, low-income students. Studies show that very few students of color are enrolled in advanced courses, but they are overrepresented in special education and remedial courses (Pitre, 2014).

Above and beyond the broader issue of fairness and ensuring every child has an equal opportunity to learn, the academic achievement gap also has serious social and economic consequences. However, closing the achievement gap has proven to be an extremely difficult task, to say the least. Despite decades of efforts and investments of educators, policymakers, and politicians to understand and dismantle the systems and structures in schools that consistently deny low-income, minority students access to quality education, minimal progress has been made towards educational equity across racial and ethnic lines, and disparities continue to grow between low and highincome students. If the academic achievement gap is closed, education equity will be achieved, which in turn will bring more upward mobility for the poor and break the cycle of intergenerational poverty and inequality (Zhao, 2016).

\subsection{Theoretical Perspective}

A significant body of research has focused on the impact of school choice on racial and socioeconomic stratification. Social stratification describes the way in which different groups of people are placed within society, based on factors like income, race, education, and power. 
Minority children are more likely to be from low-income families whose members attained low levels of education, which place them at the bottom of the social hierarchy (Oyserman \& Lewis, 2017). In research on education and stratification, educational attainment is well understood as a resource. Education is an important form of currency in systems of social stratification, as it opens up avenues for social mobility. Generally, educational credentials allow one to achieve occupations with promising career ladders, greater autonomy, and higher incomes.

It can be argued that education is one of the most important forms of cultural capital in the structures of inequality in the U.S. This durable resource provides an important context in which most Americans are led to attempt to maximize their child's life chances by seeking out a quality education (Sikkink \& Emerson, 2008).

\section{Method of Analysis}

This paper examines NCLB through the lens of comprehensive framework that presents components of social problem analysis and is organized primarily around elements of a value-critical policy analysis, as described by Chambers and Bonk (2013), from which five evaluation criteria were selected. These criteria include: (1) goals and objectives; (2) forms of benefits or services delivered; (3) entitlement or eligibility rules; (4) service delivery; and (5) financing method. In order to make the analysis more rigorous, two other policy analysis models, Gilbert and Terrell (2002) and Dolgoff and Feldstein (2003), are integrated into the process. The values, alternative, and theories that underline NCLB are discussed using framework provided by Gilbert and Terrell. Lastly, the evaluation component of Dolgoff and Feldstein's policy analysis model is incorporated to examine issues related to adequacy, cost, coherence, and latent consequences of NCLB. Thus, a thorough and efficient seven-step model (see figure 1) is used to evaluate the impact and effectiveness of policy designed to expose educational inequalities in the U.S. and close the academic achievement gap between poor minority students and their more advantaged peers. A review of the literature focused on the implementation and evaluation of NCLB provided data presented throughout the policy analysis.

\subsection{Problem Definition}

Chambers and Bonk (2013), suggest using social problem analysis to design and analyze social policies and programs and to judge their fit to the social problem. This model adopts three of the four components of social problem analysis to present the social problem that NCLB seeks to address, which includes problem definition, causes and consequences, and gains and loses. The problem definition component describes who is defining the problem, how many people are affected, and the amount of destruction to society the unaddressed problem has. The causes and consequences component considers the causal explanations that are offered for the existence of the social problem, and also discusses the consequences that follow from the social problem. Lastly, gains and loses focuses on who wins and who loses, as well as what kinds of gains and losses are involved (Chambers and Bonk, 2013).

The academic achievement gap that separates low-income, minority students from their more affluent White peers remains a shameful reality in the United States. The National Center for Educational Statistics (NCES), which is a part of the U.S. Department of Education, states the achievement gap occurs when one group of students, such as students grouped by race/ethnicity, socioeconomic status, gender, grade level, etc. outperforms another group and the difference in the two groups is statistically significant (Pitre, 2014). The term "achievement gap" and accompanying data has become synonymous with educational inequality, in recognition of the unequal educational and social structures in the U.S. that consistently deny historically underserved and marginalized students equal opportunities to receive quality education, which they are entitled to (Zhao, 2016).

Low-income, minority families have sought education as a pathway for economic mobility, empowerment, social transformation, and to influence policy (Howard \& Navarro, 2016). Educational attainment is one of the most important determinants of life chances in terms of employment, income, health status, housing, and many other amenities. Better-educated students earn higher incomes, live healthier lives, pay higher taxes, and prove less likely to be involved in crime. This social reality means the persistent patterns of poorer educational outcomes for economically disadvantaged children of color will contribute to the persistence of inequalities in socioeconomic status and race in other areas of life (Grogan- Kaylor \& Woolley, 2010).

Educational inequality is typically viewed as a challenging public policy issue because of its implications for justice. If life chances depend so heavily on education, it is important that education inequalities be addressed in order to equalize opportunities in a democratic society. 
Above and beyond the broader issue of fairness, an excellent education for all of America's children has benefits not only for the children themselves but also for the taxpayers and the larger society. According to Belfield and Levin (2007), poor education leads to large public and social costs in the form of lower income and economic growth, reduced tax revenues, and higher cost of public services such as health care, public assistance, and criminal justice. Therefore, efforts to improve educational outcomes for low-income, minority students can be viewed as a public investment that yields benefits in excess of investment costs.

\subsection{Goals and Objectives of NCLB}

According to Chambers and Bonk (2013), a goal conveys a clear idea of what the program or policy wishes to accomplish. A goal is expressed in general abstract terms, while an objective is a statement of desired outcomes that must be expressed in specific and measureable terms. Objectives must also clearly specify whose circumstances or surroundings are the target of change efforts. The goals and objectives of should answer the question: "What is the purpose of this program or policy?" All elements of a policy analysis are evaluated on the basis of their contribution to the goals and objectives. Additionally, Gilbert and Terrell (2010) emphasize the need to consider the social values that support the policy; the range of alternative ways of achieving the policy objectives; and the theories or assumptions that underlie the policy.

The intended outcome of NCLB was to ensure that every child in public school has equal access to a high-quality education and boost student achievement in reading and mathematics by 2014 nationwide. Based on the philosophy that setting high standards and establishing measurable goals for schools would improve individual outcomes for public school students, NCLB was founded on four primary objectives: increasing accountability for states, school districts and schools; giving parents and students greater flexibility in terms of transferring to another public school if the current school is not making adequate yearly progress and has been identified as needing improvement; increasing flexibility to decide how best to use federal education funds awarded to school in recognition of strong state test results; and finally, promoting the President's Reading First initiative in support of high-quality reading instruction programs designed to give children the fundamental knowledge and skills necessary to succeed in school and beyond (Odland, 2008).

The target of these change efforts were groups who have historically been poorly served and are often forgotten by American schools, including children from low-income families, children of color, children whose first language is not English, and children with disabilities. The values underpinning NCLB are equality and liberty. NCLB sought to improve education for all students by guaranteeing equal access and creating equal opportunities for low-income and minority children. School choice, as embedded in NCLB, assumes that giving parents freedom and choice to seek educational environments that will maximize the opportunities of their children and stimulate the competition necessary for school improvement (Olson Beal \& Hendry, 2012). School choice policy rests on rational choice theory, in which parents gather information about the quality of services that schools offer and then make a rational decision to enroll students in high-performing schools In an attempt to strengthen accountability for states, school districts and schools, NCLB required states to introduce annual testing of public school students in reading and mathematics in grades three through eight, and at least once in grades ten through twelve. It also specified that all schools were expected to make adequate yearly progress (AYP) towards ensuring students reach proficiency by 2014 (Murnane, 2007). NCLB mandated sanctions and rewards based on each school's AYP status. School receiving Title I funding that persistently failed to demonstrate adequate yearly progress for all students are subjective to corrective actions that could ultimately include replacement of staff and school restructuring.

School choice gives parents and students greater flexibility to transfer out of a failing school. NCLB allowed states, school districts, and school to decide how to use federal education funds awarded for achievement. Lastly, federal funds were used to promote reading programs for K-3 students, which included $\$ 250$ million for school library resources (Odland, 2007).

\subsection{Form of Benefits and Services Delivered}

There are various types and form that government benefits and services can take as ways of responding to social problems. Two forms of benefits and services offered through the passing of NCLB were power over decision and positive discrimination. Power over decisions is the right to make decisions that serve self-interests of a particular group with which the decision maker is affiliated. Positive discrimination is a benefit that is directed to protected groups to redress past inequalities (Chambers \& Bonk, 2013). 
Parents have been demanding more alternatives and a more active role in choosing schools that they believe will provide better education for their children. NCLB requires states and school districts to provide parents and children in struggling schools information regarding school choice options and supplemental services that may be available for their children. School choice offers students in low-performing public schools, to which they are assigned based on residence, the opportunity to transfer to a higher-performing public school in the district, included charter schools. (Thomas, 2011).

Alternatively, children from low-income families who attend a Title I school that has been identified by the state as in need of improvement are given the opportunity to receive free supplemental services, such as tutoring or remedial help, provided outside the regular school day, from a variety of state-approved providers. Parents have the opportunity to choose the provider that best meets the needs of their children. NCLB draws attention to improving the academic skills of historically oppressed and underserved students, including children from lowincome families, children of color, children whose first language is not English, and children with disabilities (Murnane, 2007).

The U.S. Department of Education reports a number of surveys and studies found that parents are more satisfied with their children's education when they can choose their children's schools. Furthermore, school choice programs have introduced competition into public school systems, which forces low-performing schools to become more efficient or risk losing students to higher-performing schools (Olson Beal \& Hendry, 2012).

\subsection{Entitlement or Eligibility Rules}

Eligibility rules determine: who gets what? how much? and under what conditions? Judicial decisions are important sources of eligibility. Brown v. Board of Education (1954), the U.S. Supreme Court ruled that all children are entitled to an equal opportunity for education, regardless of race. It was truly a landmark decision and marks the beginning of an era of efforts to establish civil rights, benefits, and services. This ruling not only prevented exclusion of students of color from equal access to education but also positively asserted eligibility where none existed before.

Attempting to ensure all children fair and equal access to a high-quality education, NCLB applied to all public schools. According to NCLB, public schools receiving Title I funding, and that have been identified by the state as needing improvement, corrective action, or restructuring for two or more consecutive years, must allow parents the option to transfer their child out of the public school to which they normally would be assigned based on residence to another public school, including charter schools, or provide free tutoring, remedial help, or other academic instruction (Thomas, 2011).

\subsection{Service Delivery}

Service delivery is the how of social policy analysis. Chambers \& Bonk(2013) offer several criteria specifically for evaluating service-delivery systems. For example, benefits and services should be (a) integrated and continuous; (b) accessible to clients and beneficiaries; and (c) the organization delivering them should be accountable for its actions and decisions. Supplemental educational services (SES) are a core provision of NCLB that introduces a federally mandated intervention for schools that fail to meet yearly progress benchmarks. In most cases, children from low-income families enrolled in Title I schools that have not made AYP for three years or more can receive SES. These services must be provided outside of the regular school day. SES may include tutoring and after-school services and may involve public or private sector providers approved by the states, such as local educational service agencies, private companies, and faith-based organizations. Private sector providers may be either for-profit or not-for-profit entities (Burch, Steinberg, Donovan, 2007). NCLB requires states and school districts to provide access to publicized, detailed information on school-specific performance. Written in an easy-to-read format, these "report cards" ensure that parents and taxpayers know which schools are achieving and how they are achieving (Dee and Jacob, 2011). Additionally, if a school fails to make AYP for two consecutive years, it must notify the parents that the students are permitted to transfer to another school in the district (Sanders, 2008).

\subsection{Financing Method}

Most social policies and programs cannot carry out their function without a source of funding. The greatest ideas for ameliorating social problems will fail if there are not appropriate funding streams in place to bring them to reality (Chambers \& Bonk, 2013). Taxes are the vehicle by which the government funds its activities, which is usually dispersed through either categorical grants or block grant funding. 
As discussed below, Title I funding, the statutory provision that is most associated with NCLB, was initially dispersed as a categorical grant to improve the academic achievement of the disadvantaged. As a result, everyone who met the criteria for accessing the funding received it. However, Title I funding is currently dispersed through block grants, which allows much more flexibility for how funds are spent.

In 1965, Title I funding, a provision of the Elementary and Secondary Education Act (ESEA),was explicitly allocated to children of low-income families.

As part of President Lyndon B. Johnson's War on Poverty, Title I funding was paid directly to the school to provide educational services for low-income students as opposed to a block grant that would serve the general needs of the district or schools. ESEA allowed schools to use Title I funds to implement supplemental services that addressed students' needs, including medical and dental services, parental counseling services, and meal plans. Currently, the purpose is to ensure that all children have a fair, equal, and significant opportunity to obtain a high-quality education; therefore, the statute now provides block grants to Title I schools rather than direct aid to low-income students. As a result, low-income students get a smaller percentage of the grant to themselves, as funds are dispersed to assist all the students at the school. There is often not enough funding to provide comprehensive poverty-related programs in schools, as the money typically only covers the cost of administering the standardized tests that are the primary focus of NCLB (Sanders, 2008).

\subsection{Evaluation}

The evaluation component, as described by Dolgoff and Feldstein (2003), considers issues related to adequacy, cost, coherence, and latent consequences. By evidence of the continual widening of the academic achievement gap between low-income, minority students and their more affluence white peers, NCLB was neither adequate nor efficient in achieving its goals and objectives. Additionally, competing values, insufficient funding, and losing sight of the target of change efforts produced unintended consequences. While the social problem was clearly defined, many argue that the goals and objectives of NCLB were not attainable and lacked concrete meaning. Therefore, the benefits and services of NCLB did not adequately meet the needs of the target population, which were children from low-income families, children of color, children whose first language is not English, and children with disabilities. For example, while school choice advocates maintain that school choice fosters racial integration by increasing access to quality schools for low-income and minority children, opponents argue that school choice policies gives privilege to middle-class, professional parents with the knowledge and flexibility to navigate complex school choice systems (Olson Beal \& Hendry, 2012).

Both liberty and equality were underpinning values of NCLB. While both values are desirable, they both cannot be maximized at once, as more of one will inevitably result in less of the other (Moroney, 1981). In the case of NCLB, the emphasis on absolute liberty granted by school choice lead to individualistic and competitive attitudes and, ultimately, segregated, homogeneous student populations. Therefore, one value should have been given primacy over the other. The U.S. Department of Education reports that millions of children are eligible for the school choice option, but less than $1 \%$ have benefited. NCL B requires that a school that fails to make AYP for two consecutive years must notify the parents that the students are permitted to transfer to another school in the district (Sanders, 2008). However, low-income parents are less informed and less likely to be able to acquire accurate information about schools, resulting in information stratification that renders the school choice process more treacherous (Olson Beal \& Hendry, 2012).Another concern raised by scholars regard school choice is that higher-performing, non-Title I schools generally will not accept students coming from a underperforming school, as these students bring no additional resources to the school and might lower their school's test scores.

Dee and Jacob (2011) report that NCLB's test-based school accountability had negative effects on the broad cognitive development of children, as educators were forced to shift resources away from important but nontested subjects, such as social studies, art, music, etc., and to focus instruction in math and reading on the relatively narrow set of topics that are most heavily represented on the high-stakes tests. On the other hand, higher quality teachers are often discouraged from teaching at lower-performing schools due to mandated sanctions under NCLB that often include staff and faculty changes. Teachers want to teach in schools that offer them both a steady job and much more say over what and how they teach.

\section{Discussion}

Although The Every Student Succeeds Act (ESSA) replaced NCLB in 2015, school choice is a key element of NCLB; therefore, NCLB was examined in order to evaluate the impact and effectiveness of school choice. 
Due to the aforementioned unintended consequences of NCLB, it is unlikely that many low-income students will gain access to better education through school choice options. School with high concentration of low-income and minority students consistently perform more poorly than wealthier school. They will, therefore, fail to meet AYP, requiring them to be sanctioned. When these schools are sanctioned they repel the more qualified teachers. Supplemental educational services may help to some degree; however, the educational environment of the schools will continue to deteriorate while students eligible to transfer out are unable to.

While the intention of school choice was to promote racial integration by increasing access to quality schools for low-income and minority children, many opponents of school choice argue that it exacerbates racial segregation and social class stratification. Research indicates white parent are more likely to choose an alternative to the local public school for their children or have their children in racially homogenous schools, as White Americans perceive the higher the percentage of black student enrollment, the lower the quality of that school. Although Sikkink and Emerson (2008) found that previous work on schooling decisions suggests that race overpowers concern for school quality, more research is necessary to test what exactly White parents are reacting to when they remove their children from schools with a high proportion of black students.

\section{Conclusion}

Racial and socioeconomic distributions strongly shape school choices, as segregation over the past decade in primary and secondary schools has continued to rise. Therefore, interventions to eliminate the academic achievement gap cannot fully succeed as long as social stratification caused by socioeconomic conditions and ethnicity is not addressed. Additionally, poor and minority parents need to be informed about how to exercise choice about all the options available. These parents need rich information about what different schools offer and how effective they are with children who have different interests and learning styles, as such information is not readily available now.

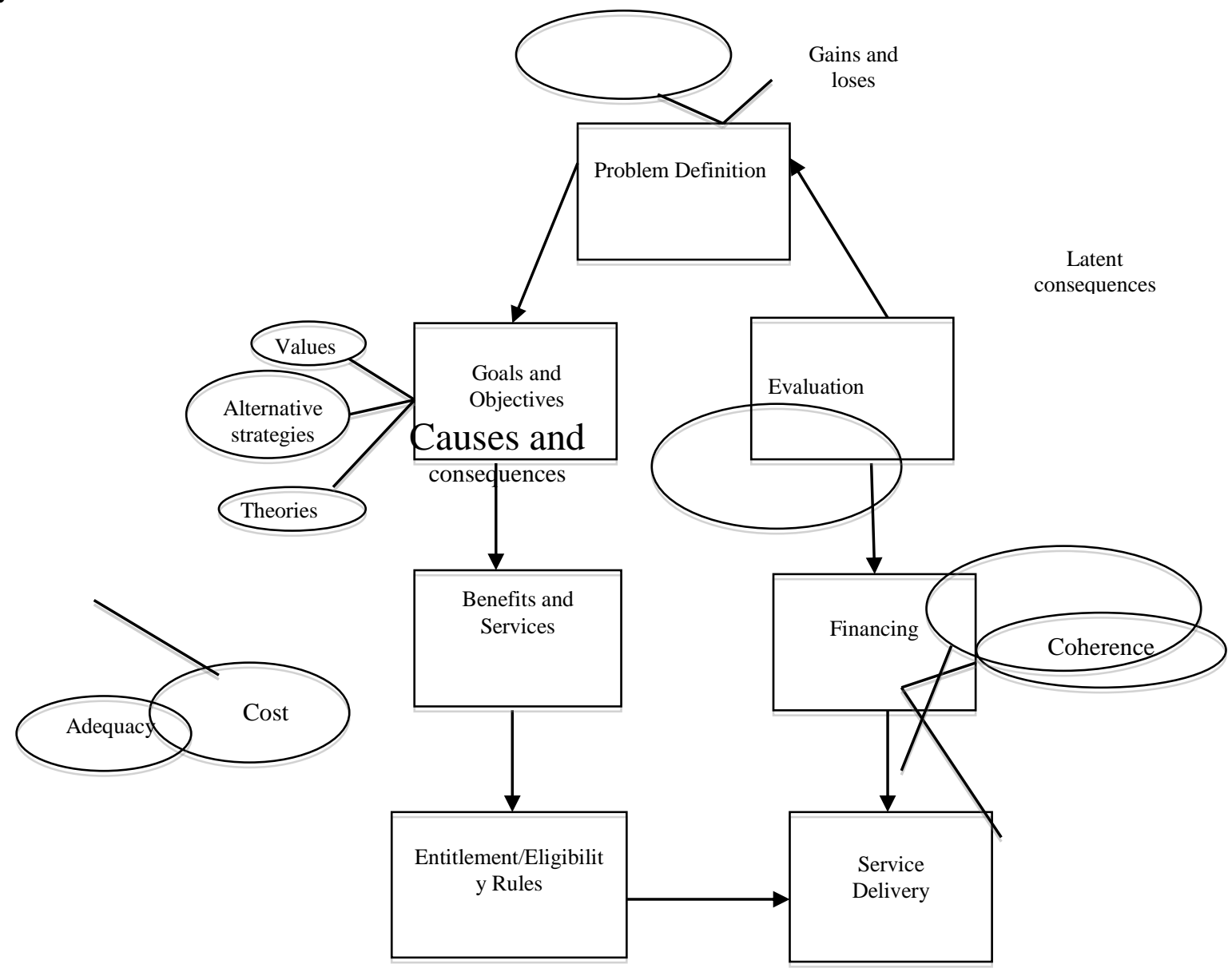

Figure1. Value Analytical Policy Analysis Model 


\section{References}

Belfield, C., \& Levin, H. (2007). The education attainment gap: Who's affected, how much, and why it matters. In C. Belfield \& H. Levin (Eds.), The price we pay: Economic and social consequences of inadequate education (1-18). Washington, D.C.: Brookings Institution Press.

Burch, P., Steinberg, M., \& Donovan, J. (2007). Supplemental education services and NCLB:Policy assumptions, market practices, emerging issues. Educational Evaluation and Policy Analysis, 29(2), 115-133.

Chambers, D.E. \& Bonk, J.F. (2013). Social policy and social programs: A method for the practical public policy analyst (6th ed.). Boston, MA: Pearson Education, Inc.

Dee, T. S., \& Jacob, B. (2011). The impact of no child left behind on student achievement. Journal of Policy Analysis and Management, 30(3), 418-466.

Dolgoff, R., \& Feldstein, D. (2003). Understanding social welfare (6th ed.). Boston: Allyn \&Bacon.

Ford, D. Y. (2011). Closing the achievement gap: Gifted education must join the battle. Gifted Child Today, 34(1), 31-34.

Gilbert, N., \& Terrell, P. (2010). Dimensions of social welfare policy ( $7^{\text {th }}$ ed.). Boston: Allyn \& Bacon.

Grogan- Kaylor, A. \& Woolley, M. E. (2010). The social ecology of race and ethnicity school achievement gaps: Economic, neighborhood, school, and family factors. Journal of Human Behavior in the Social Environment, 20, 875-896.

Howard, T. C., \& Navarro, O. (2016). Critical race theory 20 years later: Where do we go from here? Urban Education, 51(3), 253-273.

Moroney, R. M. (1981). Policy analysis within a value theoretical framework. In R. Haskins \& J.

J. Gallagher (Eds.), Models for analysis of social policy: An introduction (78-101). Norwood, NJ: Ablex Publishing Corporation.

Murnane, R. J. (2007). Improving the education of children living in poverty. The Future of Children, 17(2), 161182.

Nielsen, N. (2013). Education, equity, and the big picture. Issues in Science and Technology, 29(3), 76-82.

Odland, J. (2008). The law in review. Childhood Education, 84(2), 94B-94C.

Odland, J. (2007). NCLB: Time to reevaluate its effectiveness. Childhood Education, 83(2), 98B.

Olson Beal, H. K., \& Hendry, P. M. (2012). The ironies of school choice: Empowering parents and reconceptualizing public education. American Journal of Education, 118(4), 521-550.

Oyserman, D., \& Lewis, N. A. (2017). Seeing the destination and the path: Using identity-based motivation to understand and reduce racial disparities in academic achievement. Social Issues and Policy Review, 11(1), 159-194.

Pitre, C. C. (2014). Improving African American student outcomes: Understanding educational achievement and strategies to close opportunity gap. Western Journal of Black Studies, 38(4), 209-217.

Sanders, A. (2008). Left behind: Low-income students under the no child left behind act (NCLB). Journal of Law and Education, 37(4), 589-596.

Sikkink, D. \& Emerson, M. O. (2008) School choice and racial segregation in US schools: The role of parents' education. Ethnic and Racial Studies, 31(2), 267-293.

Thomas, R. (2011). Deconstructing school choice: Problem schools or problem students? Public Administration Review, 70(1), 87-95.

U.S. Department of Education (2015). The Nation's Report Card. National Assessment of Educational Progress. Retrieved from https://www.nationsreportcard.gov/reading_math_2015/

Welsh, R. O. (2018). Student mobility, segregation, and achievement gaps: Evidence from Clark County, Nevada, Urban Education, 53(1), 55-85.

Zhang, H. C., \& Cowen, D. J. (2009) Mapping academic achievement and public school choice under the No Child Left Behind legislation. Southeastern Geographer, 49(1), 24-40.

Zhao, Y. (2016). From deficiency to strength: Shifting the mindset about education inequality. Journal of Social Issues, 72(4), 720-739. 